\title{
Analyzing Influential Factors of Lean Management
}

\author{
Wen-Hsiang Lai ${ }^{1}$, Hsien-Hui Yang ${ }^{2}$ \\ ${ }^{1}$ Department of Business Administration, Feng Chia University, Taiwan \\ ${ }^{2} \mathrm{Ph}$. D. Program of Business, Feng Chia University, Taiwan \\ Correspondence: Hsien-Hui Yang, Ph. D. Program of Business, Feng Chia University, Taiwan. \\ E-mail: magiyang99@gmail.com \\ Received: December 22, 2016 \\ Accepted: January 16, 2017 \\ Online Published: February 8, 2017 \\ doi:10.5539/ibr.v10n3p20 \\ URL: http://dx.doi.org/10.5539/ibr.v10n3p20
}

\begin{abstract}
The study explores the key factors influencing Lean management and evaluates their individual weights to identify what leads to a successful hospital management. It adopts the 4P Excellence Model in Lean management to assess and measure the healthcare organizations from the five perspectives: leadership, people, partnership, processes, and products. To explore the potential factors, the study employs the analytic hierarchy process (AHP) method and multi-expert judgment to prioritize the significance of each factor. The study has led to a number of useful insights. Processes are crucial when hospitals advocate lean management. Among the 18 sub-factors in the five criteria, the most significant factors include patient-centered care, clearly defined work content, rewarding teamwork effort, continual learning and upgrading, and increasing the clinic quality. To satisfactorily carry out Lean management, a hospital should continuously strive for improvement, pursue perfection, engender organizational culture, strengthen teamwork, and create mutual trust among team members. Moreover, patient-centered care beliefs should be actively implemented. To provide seamless care, patients and their families should be the main foci. The results could be used by hospital managers to improve their skills and knowledge when implementing Lean management. In addition, the framework developed herein could potentially lend itself to many practical applications.
\end{abstract}

Keywords: healthcare delivery, lean management, 4P excellence model, AHP method

\section{Introduction}

Healthcare delivery is a vital issue in the global social welfare system. Healthcare delivery has been on the decline due to rising medical expenses and increasing frequencies of chronic diseases as the population is aging fast. Moreover, the waste of medical resources aggravates these problems, which leads to poor medical services. To address such problems in order to enhance financial performance and sustainability, healthcare professionals and managers throughout the world have been experimenting with Lean methods to improve healthcare efficiency, clinical outcomes, and satisfaction, as well as safety for both staff and patients (D'Andreamatteo et al., 2015). Adopting Lean management could help healthcare providers bring in large profits and elevate their competitiveness within the healthcare industry.

In 1995, Taiwan launched the National Health Insurance (NHI), which operates based on a fee for service (FFS) system (Taiwan Healthcare Reform Foundation, 2016). The patient needs to pay an amount of fees set by the National Health Insurance Administration (NHIA) for each medical service received, while the rest of the payment for the service is covered by the NHIA. Taiwan's healthcare delivery system is market-driven. A hospital has two types of large outpatient departments and affiliated clinics for primary care. The laissez-faire policy has greatly impacted the quality of medical care for many years (Lu \& Hsiao, 2003).

In Taiwan, patients are free to choose either a hospital or a clinic. There are no incentives for the patients to accept the referral suggested by the physician; instead, their preference and information dominate their decision. Easy access to medical treatment has led to the abuse of healthcare services. To prevent unlimited spending, the NHIA introduced "the global budget system" to modify the FFS mechanism. The global budget puts an expenditure cap on each medical field. If the total services performed exceeded the field's budget quota, then the FFS reimbursement ratio would start to deflate, which would shrink the payment for each service performed (Taiwan Healthcare Reform Foundation, 2016). The deflation mechanism of the global budget would affect every contracted medical institution. If the total service exceeded the quota, then the payment would shrink; in 
some circumstances, the healthcare providers would tend to work extra hours or seek other ways to cover the losses. For cost-effectiveness, the physicians tend to focus more on profit than on patient treatments. Consequently, healthcare institutions and their medical processes have incurred much more waste and ineffectiveness.

The implementation of the National Health Insurance has changed the medical ecology and healthcare practice in Taiwan. Healthcare organizations are undergoing fundamental changes. The rapid pace of change presents tremendous challenges for healthcare managers. These changes include the healthcare systems, science and technology, new incentive structures and technologies, moral attitudes, environmental conditions, and rising costs. To address these challenges, for many years, the healthcare industry has initiated quality improvements, such as Total Quality Management (TQM) and Continuous Quality Improvement (CQI). However, these initiatives lost incentives and acceptance due to their lack of data driven analyses. Moreover, many managers and physicians became disappointed with the prospects of quality improvement (Noori, 2015). Traditional performance measurement systems (PMSs) have failed to measure and integrate the factors that are critical to the success of a business (Su et al., 2014).With the multifunctional market and the challenging environment, new PMSs have been proposed: the Activity-Based Costing System (Koota \& Takala, 1998), the Balanced Scorecard (Kaplan \& Norton, 2005), the SMART System (Hudson et al., 2001), and the Performance Measurement Questionnaire (Park et al., 1998). Numerous approaches for proposing the criteria for the design of PMSs exist; however, these proposed approaches failed to cope with the complex problems of the healthcare industry. To face the harsh challenges of the competitive market, the healthcare industry needs a comprehensive initiative.

The healthcare industry is a specialized field as it includes complex processes, expertise, delicate instruments, and a fluent workflow process, which are all associated with a successful operation of a hospital. Lean management teaches us to see quality improvement as a means to cost reductions, a better approach than focusing directly and solely on costs. If effectively using Lean principles, a top tier of hospitals will emerge. Therefore, the objectives of this study are to explore the key factors that influence Lean management and evaluate their individual weights to identify what leads to successful hospital management. The aim is to propose a framework of Lean management that can be applied in hospital.

\subsection{Theoretical Foundation of Lean Management}

The concept of Lean management originated from the Toyota Motor Corporation. As Womack and Jones (2005) noted, Lean management was initially developed to improve car production; yet, its essence could be applied to any healthcare system, as a great number of studies have documented that Lean is an effective way to improve healthcare organizations (Poksinska, 2010; Aguilar-Escobar et al., 2015). For the past few years, the healthcare industry, with dwindling budgets and a soaring healthcare demand, has been confronted with tremendous pressure. Consequently, embracing "Lean thinking" is inevitable if one would like to achieve "more" with "less" (Poksinska, 2010).

Lean management has been introduced to improve quality in healthcare in recent decades. The fundamental goal of Lean is to determine how to do the right thing, how to eliminate waste, and how to change procedures flexibly enough for effective improvement. Value is the key to the concept of Lean management, and the customers determine the value. A product (or service) is valuable if it meets a customer's needs under a fixed time and price (Womack \& Jones, 2005). Modern healthcare organizations are comprised of complex processes, and they are in significant need of improvement in the domains of safe, efficient, timely, and appropriate delivery of care to patients. The goal of Lean management in healthcare is to continuously focus on the large and small changes that must be made in the processes of how clinical care is delivered so that healthcare can be delivered in a way that simultaneously optimizes quality, safety, efficiency, and appropriateness. The principles of Lean management require frequently redesigning medical procedures in order to remove waste and continue to improve the support structure for all of the hospitals' medical services (Papadopoulos et al., 2011).

There has been extensive evidence in the literature that Lean management has been instrumental in increasing the healthcare system's capacity without any extra cost (Johnson \& Mastro, 2012; Poksinska, 2010; Graban, 2016). If adopting Lean management can lead to significant outcomes, then managers need to understand it, and identify how to best structure their initiatives to achieve its benefits. Lean management has been implemented in some large-scale hospitals in Taiwan for improving medical quality and services. However, since there are different criteria and lack of evaluative decisions while promoting the Lean management, it becomes more difficult to deploy Lean management in healthcare industry.

Taiwan is facing a formidable challenge in which many historic business models and operating processes will no longer suffice amid rising demand, continued cost pressures, lack of or inadequate care facilities, and rapidly 
evolving market conditions. There is agreement that healthcare reform is essential to reach both low cost and high quality; Lean is a method to help medical institutions realize their goals of upgrading the healthcare quality. There are many hospitals using Lean methods to elevate and enhance their healthcare qualities.

\subsection{The Application of Goal Theory}

In this study, goal theory is used to make up the lack of theoretical foundation of Lean practices. Goal theory has existed for many years. It has been extensively studied in academia and has become a large part of practitioners' efforts to improve organizational performance (Langabeer et al., 2009). The healthcare industry has focused on improved qualities (e.g., TQM, CQI), which are not widespread and have failed to meet managers' and physicians' expectations due to the lack of data-driven analyses (Linderman et al., 2003). Goal theory emphasizes the cognitive process and intentional behavior, and it offers a theoretical basis to help understand the relationship between goal setting and goal attainment (Locke, 1970).

The importance of setting goals is determined by task performance in today's competitive business environment. Goals encourage innovation by developing improved strategies to finish a task, which motivates employees and organizations to pay attention to relevant problems for enhancing performance. According to goal theory, hospital's managers set goals for eliminating waste and improving medical service, and then, they check and modify the defective procedures in goal setting and goal attainment (Parast, 2010).

\subsection{The Criteria for Lean Management}

Many hospitals have been promoting the Lean management for improving qualities and reducing costs. However, since different criteria exist and evaluative decisions are scarce while promoting the Lean management, it has become more difficult to deploy Lean management in healthcare industry. Dahlgaard-Park and Dahlgaard (2010) proposed a model, the "4P" Excellence Model, which has proven to be a good framework for assessing, measuring, diagnosing and improving innovation enablers and results, when companies are planning to attain Lean. The model's 5 components are Leadership, People, Partnership, Processes and Products, as show in Figure 1. This study adopts the 4P Excellence Model to assess and measure the healthcare organizations to cover this gap.

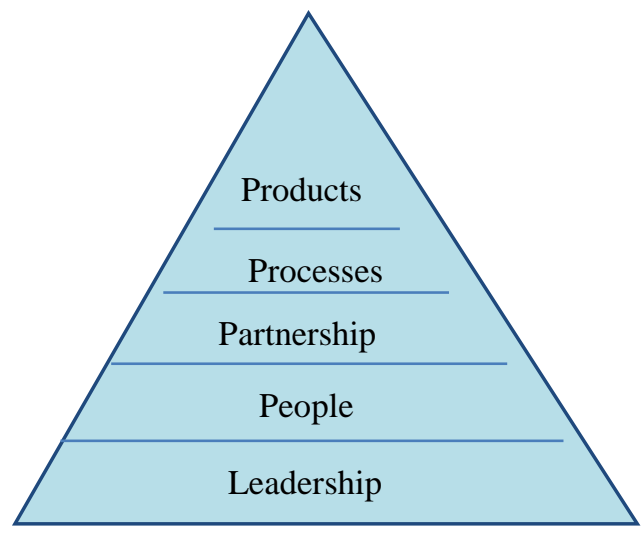

Figure 1. The "4P" Excellence Model

Figure 1 indicates that the model starts with Leadership at the bottom, which requires building a culture with norms and values that supports innovation and new product development. It resulted from intentional long-term activities as well as careful thinking, reflection, planning, and measurements (Dahlgaard-Park \& Dahlgaard, 2010; Marx, 2015). The next step up is People, which is to educate and train people with the right values and competencies. The leaders and their people will together integrate creativity and motivate as well as manage knowledge and learning (Dahlgaard-Park \& Dahlgaard, 2010; Graban, 2016). Partnership requires establishing and developing teams that are able to practice the right and needed values and competencies. A partnership is formed in all people relationships, including within the team, between team members, between teams, and with other people or groups outside of the team (Xyrichis \& Ream, 2008; Dahlgaard-Park \& Dahlgaard 2010). Processes means that leaders, individuals and teams gradually try to practice the needed values and competencies based on the principle of continuous improvement and the organization's mission, vision, goals, and strategy (Dahlgaard-Park \& Dahlgaard 2010; Khalifa, 2012). Products on top of the hierarchy refer to melting quality into tangible and intangible products (or services) through a ceaseless focus on customers' needs and market potential. It also requires practicing the principles of constant improvement in parallel with innovativeness in product development (Dahlgaard-Park \& Dahlgaard 2010). 


\section{Method}

The aim of this study is explore the key factors that influence Lean management and propose a framework that can be applied in a hospital management. There are some steps to follow in carrying out this study. First, established were a hierarchical structure and the influencing factors, based on a thorough literature review and an initial interview to select the criteria to formulate a questionnaire. Next, formulated was the questionnaire by screening the factors through the Fuzzy Delphi Method (FDM). Finally, the Analytic Hierarchy Process (AHP) method was adopted to calculate the weight of the influence factors and test the consistency.

\subsection{Fuzzy Delphi Method}

The FDM was derived from the traditional Delphi technique and fuzzy set theory (Ishikawa et al., 1993). One of the most important problems is to solve the fuzziness of the expert consensus within the group's decision-making. This method solved not only the shortcomings of the conventional Delphi method but also the effects of the Delphi method that are easily affected by extreme opinions. The functions are calculated using triangular fuzzy numbers with maxima and minima as the two extreme values, which indicate the tolerance range of the selected factors. The geometric mean represents all of the trigonometric functions of the evaluation consensus reached by the expert groups (Hsu et al., 2010). The last objective of the study is to select the appropriate threshold value $\alpha$ as the standard filter selection factor.

\subsection{Analytic Hierarchy Process}

AHP is considered to be a decision method that decomposes a complex multi-criteria decision problem into a hierarchy using experts as the objects of a questionnaire (Saaty, 1980). Through a set of pairwise comparisons at each level of the hierarchy, a matrix can be developed in which the entities indicate the strength with which one element dominates another with respect to a given criterion. AHP is a principle of measurement through pair-wise comparisons and relies on the judgment of experts to derive the priority scales. These scales measure the intangibles in relative terms. The comparisons are made using a scale of absolute judgment that represents how much more one element dominates another with respect to a given attribute (Vinodh et al., 2012). AHP judges and selects the elements/concepts that have a greater influence on the predetermined objective.

\subsection{Evaluating Model Applications}

In evaluating model applications, four steps are taken: Proposing important criteria, Screen important criteria using Fuzzy Delphi Method, Establishing a hierarchical framework, and Calculating the weights of the evaluation criteria.

1) Proposing important criteria: The influencing factors for Lean management based on reviewing relevant literature selection approach are proposed. Definitions of the evaluating criteria of the Lean management selection are presented in Table 1 and Table 2.

Table 1. Operational definition of criteria

\begin{tabular}{ll}
\hline \multicolumn{1}{c}{ Criteria } & \multicolumn{1}{c}{ Operating definition } \\
\hline Leadership & $\begin{array}{l}\text { This is the capacity to influence others through a dynamic, reciprocal covenant aimed toward } \\
\text { identifying and accomplishing collective purposes, which a process that uses communications } \\
\text { to motivate members and to promote teamwork (Crema \& Verbano, 2013; Marx, 2015). }\end{array}$ \\
\hline People & $\begin{array}{l}\text { This emphasizes a clear list of work types, offering continual training and counseling to } \\
\text { personnel to motivate their innovation and involving personnel in decision making, with the } \\
\text { hope of enhancing work devotion (Graban, 2016). }\end{array}$ \\
\hline \multirow{3}{*}{ Partnership } & $\begin{array}{l}\text { This is about stabilizing mutual trust among different departments, which is used to enable } \\
\text { the sharing of information, the accomplishment of objectives, and the establishment of } \\
\text { long-term cooperation with suppliers (Xyrichis \& Ream, 2008). }\end{array}$ \\
\hline Processes & $\begin{array}{l}\text { This is to examine the equipment and tools of the hospital by using a visible management } \\
\text { approach, the aim of which is to establish a standardized working process for continuous } \\
\text { improvement and learning, with the hope of avoiding unseen problems (Sayer \& Williams, } \\
\text { 2012). }\end{array}$ \\
\hline \multirow{3}{*}{ Products } & $\begin{array}{l}\text { This effectively helps reduce medical errors, infections, and mortality, as well as any } \\
\text { occurrence of hostile events. It aims to provide a seamless patient care environment in order } \\
\text { to meet patients' satisfaction (Gulliford et al., 2006). }\end{array}$ \\
\hline
\end{tabular}


Table 2. Operational definition of sub-criteria

\begin{tabular}{|c|c|c|}
\hline Criteria & Sub-Criteria & $\begin{array}{l}\text { Operating definition } \\
\end{array}$ \\
\hline \multirow{4}{*}{ Leadership } & Mission and Vision & $\begin{array}{l}\text { It states the value and existence of organizations. It also motivates, } \\
\text { adjusts and guides the company employees' actions, values, and } \\
\text { behaviors (Hill \& Jones, 2012). }\end{array}$ \\
\hline & $\begin{array}{l}\text { Integrated } \\
\text { Strategies }\end{array}$ & $\begin{array}{l}\text { This works through analyzing both the external and internal } \\
\text { environments in order to effectively allocate the organization's internal } \\
\text { resources for developing strategies and responding to the changes in } \\
\text { the external environment (Hill \& Jones, 2012; Dombrowski et } \\
\text { al.2013). }\end{array}$ \\
\hline & Patient-centered Care & $\begin{array}{l}\text { This is to consider patients' wishes and beliefs and to integrate } \\
\text { different professions and services based on the patients' state of health } \\
\text { for providing a coordinated and integrated care (Frampton et al., } \\
\text { 2008; Cliff, 2012). }\end{array}$ \\
\hline & $\begin{array}{l}\text { Executive Sponsorship and } \\
\text { Leadership }\end{array}$ & $\begin{array}{l}\text { This is a direct involvement by the leaders who take employees' } \\
\text { feelings and needs into consideration to provide timely assistance and } \\
\text { feedback (Mostafa et al., 2013). }\end{array}$ \\
\hline \multirow{4}{*}{ People } & $\begin{array}{l}\text { Motivating Learning } \\
\text { Innovation }\end{array}$ & $\begin{array}{l}\text { This is to motivate employees to learn and to generate new ways of } \\
\text { thinking and practice in order to apply the learned knowledge and } \\
\text { skills into work to increase organization's effectiveness, efficiency and } \\
\text { productivity (Lyle, 2012). }\end{array}$ \\
\hline & $\begin{array}{l}\text { Continual } \\
\text { Counseling }\end{array}$ & $\begin{array}{l}\text { This is to improve employees' working abilities through the guidance } \\
\text { of the organization. The learning objectives include knowledge, skills, } \\
\text { abilities and attitudes (Winston et al., 2006). }\end{array}$ \\
\hline & Clearly Defined Work Content & $\begin{array}{l}\text { This is to precisely designate responsibilities, tasks and conditions and } \\
\text { clearly helps technical professionals to concentrate on their } \\
\text { professional contents so that employees can demonstrate their } \\
\text { specialties (Graban, 2016). }\end{array}$ \\
\hline & Channels for Advice & $\begin{array}{l}\text { It is a constructive channel of commutation in which employees of the } \\
\text { organization offer constructive suggestions for improving the current } \\
\text { situation of the organization (Lyle, 2012). }\end{array}$ \\
\hline \multirow{3}{*}{ Partnership } & Cross-functional Team & $\begin{array}{l}\text { It is organized by the employees from the different departments of the } \\
\text { organization to complete the same tasks. As employees' skills } \\
\text { complement one another, they are more likely to finish the same tasks } \\
\text { effectively (Xyrichis \& Ream, 2008). }\end{array}$ \\
\hline & Rewarding Teamwork Effort & $\begin{array}{l}\text { This is to achieve the pre-set goals through joint efforts by valuing the } \\
\text { communication, the participation, the mutual trust and the cooperation } \\
\text { among the employees (Adjekukor et al., 2015). }\end{array}$ \\
\hline & $\begin{array}{l}\text { Treating Partners Fairly and } \\
\text { Equally }\end{array}$ & $\begin{array}{l}\text { This is to consider the business partners and suppliers who have a } \\
\text { long-term relationship with the organization and to help them improve } \\
\text { their competences (Jylhä \& Junnila, 2014; Graban, 2016). }\end{array}$ \\
\hline \multirow{4}{*}{ Process } & Standardized Work & $\begin{array}{l}\text { This is to define the standards of consistent and predictable works. The } \\
\text { main purpose is to improve products, processes and relevance of } \\
\text { services in order to achieve the intended purposes (Sayer \&Williams, } \\
\text { 2012). }\end{array}$ \\
\hline & Error Proofing & $\begin{array}{l}\text { This is the creation of devices or methods that either prevent defects or } \\
\text { automatically inspect the outcome of a process (Graban, 2016). }\end{array}$ \\
\hline & Visual Management & $\begin{array}{l}\text { This refers to the way of management that helps employees rapidly } \\
\text { identify problems in the production system, regardless of how } \\
\text { unfamiliar they are with the processes (Tezel et al., 2013). }\end{array}$ \\
\hline & $\begin{array}{l}\text { Continual } \\
\text { Upgrading }\end{array}$ & $\begin{array}{l}\text { This means that employees in the organization need to get involved } \\
\text { and be responsible. In addition, this is to improve the working } \\
\text { situation or process, and employees need to engage in continuous } \\
\text { learning, self-improvement and innovation, as well as knowing how to } \\
\text { use the appropriate method to solve problems (Graban, 2016). }\end{array}$ \\
\hline \multirow{3}{*}{ Products } & $\begin{array}{l}\text { Improving } \\
\text { Satisfaction }\end{array}$ & $\begin{array}{l}\text { This is the direct appraisal from the customers, concerning the } \\
\text { products and services offered by employees (Verena, 2011). }\end{array}$ \\
\hline & $\begin{array}{l}\text { Offering Continuity of } \\
\text { Care }\end{array}$ & $\begin{array}{l}\text { This means that the patient and his/her physician-led care team are } \\
\text { cooperatively involved in ongoing healthcare toward the shared goal } \\
\text { of high quality and cost-effective medical care (Gulliford et al., 2006). }\end{array}$ \\
\hline & $\begin{array}{l}\text { Increasing the Clinic } \\
\text { Quality }\end{array}$ & $\begin{array}{l}\text { This is to accurately assess the needs of the patients and understand the } \\
\text { patient's conditions entirely. This also effectively helps reduce } \\
\text { medical errors, infections, mortality as well as any occurrence of } \\
\text { hostile events (Graban, 2016). }\end{array}$ \\
\hline
\end{tabular}


2) Screen important criteria using Fuzzy Delphi Method: First, five main criteria and 31 sub-criteria were selected as the key evaluation items of Lean management in a hospital. Then, 10 experts from a medical center in central Taiwan were interviewed between June 2016 and July 2016. The interviewees, who were senior hospital managers, had served for more than a decade at the center and had participated in important decision-making, as presented in Table 3. Experts complete the questionnaires to rank the importance of the factors on a 1 10 point scale, with 10 as the most important factor. Then, the evaluation score of each alternative factor's significance given by each expert was found using linguistic variables in questionnaires. Finally, the experts' opinions found in the FDM questionnaires were converted to triangular fuzzy numbers, and the de-fuzzified values were determined after performing the calculation (Kuo \& Chen, 2008). This stage adopted elements with a threshold above 7, and the key evaluation items with a threshold below 7 were deleted (Hsu et al., 2010). The important evaluation items found after screening are listed in Table 4.

Table 3. Subject Characteristics

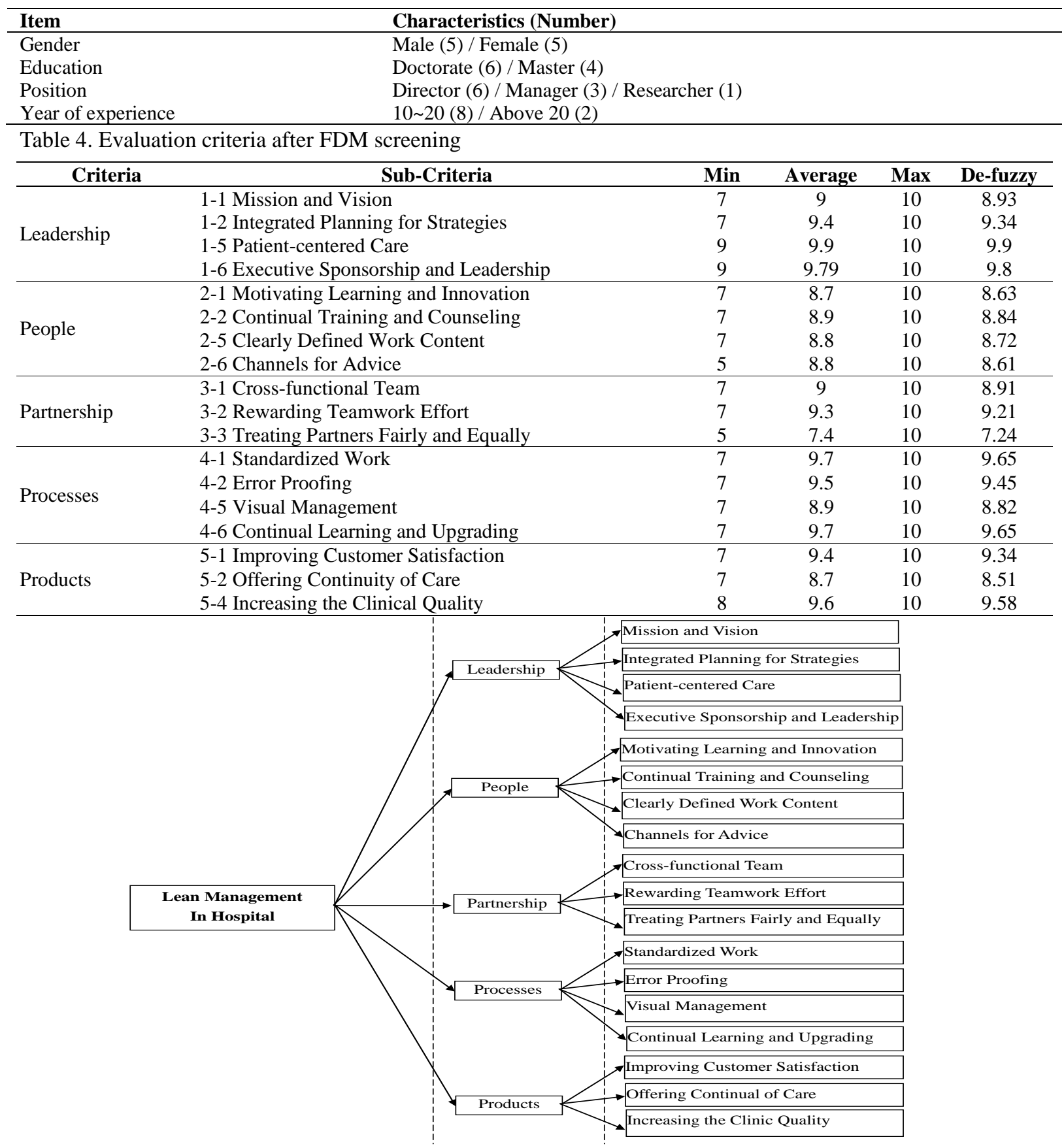

Figure 2. Hierarchical Framework of Lean Management in Hospital 
3) Establishing a hierarchical framework: Based on the FDM, a general consensus among experts was reached to establish a hierarchical structure. The Lean management in a hospital can be evaluated based on five evaluation criteria and 18 evaluation sub-criteria (Figure 2). In the second interview, 23 questionnaires were administered to 23 medical specialists from two medical centers in central Taiwan. The subjects had more than 10 years of working experience in medical fields, as presented in Table 5.

Table 5. Subject Characteristics

\begin{tabular}{ll}
\hline Item & Characteristics(Number) \\
\hline Gender & Male (11) / Female (12) \\
Education & Doctorate (6) / Master (10) / Bachelor (7) \\
Position & Director (5) / Nurse (8) / Physician (5) / Manager (1) / Researcher (4) \\
Year of Experience & $10 \sim 20$ (15) / Above 20 (8) \\
\hline
\end{tabular}

4) Calculating the weights of the evaluation criteria: In this step, a pairwise comparison matrix was first constructed through pairwise comparisons of each decision factor, using subjective judgments to determine the importance of one factor relative to another. The scale used in AHP for preparing the pairwise comparison matrix was a discrete scale from 1 to 9 , as presented in Table 6. In accordance with typical AHP design, the questionnaire analysis was performed using Expert Choice 2000 and Excel.

Table 6. Scale of the relative importance of factors

\begin{tabular}{cll}
\hline $\begin{array}{l}\text { Numerical } \\
\text { Rating }\end{array}$ & Definition & \multicolumn{1}{c}{ Explanation } \\
\hline 1 & Equal importance & Two factors equally contribute to the objective. \\
3 & Moderate importance & Experience and judgment slightly favor one over the other. \\
5 & Essential importance & Experience and judgment strongly favor one over the other. \\
7 & Very Strong Importance & $\begin{array}{l}\text { Experience and judgment very strongly favor one over the other. } \\
\text { The evidence favoring one over the other is of the highest possible }\end{array}$ \\
9 & Absolute Importance & validity. \\
$2,4,6,8$ & Intermediate values & When compromise is needed. \\
\hline 3.
\end{tabular}

\section{Results}

Table 7 displays the results of the study. The results of this AHP calculation $(C R=0.01<0.10)$ meet both the desired consistency index (CI) and consistency ratio (CR) values in the hierarchy comparison analysis, both of which should be less than or equal to 0.1, and conform to the acceptable deviation scope as suggested by Saaty (1980).

\subsection{The Ranking of the Main-criteria}

Among the five factors, the most salient one that influences the implementation of a Lean management in a hospital is Processes, with a value of 0.304 , which is followed by Products $(w=0.224)$, Leadership $(w=0.187)$, Partnership ( $w=0.165$ ), and People ( $w=0.12$ ) respectively. It indicates that hospital employees need to prioritize improve key processes and tasks for the sake of improving patient safety, preventing time delays, making work easier for employees, and reducing costs.

Table 7. Weights and the ranking levels of the main and sub-criteria

\begin{tabular}{|c|c|c|c|c|c|}
\hline Criteria & Weight $(w)$ & Rank & $\begin{array}{r}\text { Sub-Criteria } \\
\end{array}$ & Weight $(w)$ & Rank \\
\hline \multirow{4}{*}{ Leadership } & \multirow{4}{*}{0.187} & \multirow{4}{*}{3} & Mission and Vision & 0.098 & 4 \\
\hline & & & Integrated Planning for Strategies & 0.2 & 3 \\
\hline & & & Patient-centered Care & 0.411 & 1 \\
\hline & & & Executive Sponsorship and Leadership & 0.291 & 2 \\
\hline \multirow{4}{*}{ People } & \multirow{4}{*}{0.12} & \multirow{4}{*}{5} & Motivating Learning and Innovation & 0.118 & 4 \\
\hline & & & Continual Training and Counseling & 0.184 & 3 \\
\hline & & & Clearly Defined Work Content & 0.388 & 1 \\
\hline & & & Channels for Advice & 0.31 & 2 \\
\hline \multirow{3}{*}{ Partnership } & \multirow{3}{*}{0.165} & \multirow{3}{*}{4} & Cross-functional Team & 0.207 & 3 \\
\hline & & & Rewarding Teamwork Effort & 0.425 & 1 \\
\hline & & & Treating Partners Fairly and Equally & 0.368 & 2 \\
\hline \multirow{4}{*}{ Processes } & \multirow{4}{*}{0.304} & \multirow{4}{*}{1} & Standardized Work & 0.139 & 4 \\
\hline & & & Error Proofing & 0.201 & 3 \\
\hline & & & Visual Management & 0.316 & 2 \\
\hline & & & Continual Learning and Upgrading & 0.345 & 1 \\
\hline \multirow{4}{*}{ Products } & \multirow{4}{*}{0.224} & \multirow{3}{*}{2} & Improving Customer Satisfaction & 0.177 & 3 \\
\hline & & & Offering Continuity of Care & 0.349 & 2 \\
\hline & & & Increasing the Clinic Quality & 0.473 & 1 \\
\hline & & & & & \\
\hline
\end{tabular}




\subsection{The ranking of the Sub-criteria}

In this study, there are 18 sub-criteria that are derived from the five main criteria. Table 7 displays the rank of each of the sub-criteria.

Among the four sub-criteria in Leadership, Patient-centered Care receives the highest value ( $w=0.411)$, followed by Executive Sponsorship and Leadership $(w=0.291)$, Integrated Planning for Strategies $(w=0.2)$, and Mission and Vision $(w=0.098)$ respectively. Among the four sub-criteria in People, Clearly Defined Work Content ranks the highest in value $(w=0.388)$, followed by Channels for Advice $(w=0.31)$, Continual Training and Counseling $(w=0.184)$, and Motivating Learning and Innovation $(w=0.118)$ respectively. Among the three sub-criteria in Partnership, Rewarding Teamwork Effort receive the highest value $(w=0.425)$, followed by Treating Partners Fairly and Equally $(w=0.368)$ and Cross-functional Team $(w=0.207)$ respectively.

Among the four sub-criteria in Processes, Continual Learning and Upgrading received the highest value $(w=0.345)$, followed by Visual Management $(w=0.316)$, Error Proofing $(w=0.201)$, and Standardized Work $(w=0.139)$ respectively. Among the three sub-criteria in Products, Increasing the Clinic Quality receives the highest value $(w=0.473)$, followed by Offering Continuity of Care $(w=0.349)$ and Improving Customer Satisfaction $(w=0.177)$ respectively. These clearly points out what the priorities are and what should be taken into consideration first. For a hospital that adopts a Lean management, its core standards for an effective, efficient medical care should implement the concept of the patient-centered practice, which provides high-value healthcare system. Furthermore, as services increase, the types of work should be clearly defined, and professionalism should be valued if errors and delays in delivering services are to be avoided. The process of providing medical care services relies heavily on teamwork to improve medical quality, patient outcomes, and safety. Only through continuous improvement and learning, and constantly striving for quality, efficiency, patient safety, and the promotion of services, can a hospital sustain its competitiveness and profitability and provide quality services to the public.

\section{Discussion}

\subsection{The Ranking of the Main Five Factors}

According to the results, Processes is the most important factor, which clearly demonstrates that the key factors for implementing Lean management in hospitals require concentrating on process optimization. This finding contradicts the results found in the literature review, which indicate that Leadership plays a major role in adopting Lean management (Johnson \& Mastro, 2012). This finding has led us to infer that as medical services are highly timely and unique, people tend to judge the product of medical care based on whether a patient can recover after being treated. A correct process leads to an accurate result. Innovative products and services are the outcomes of a revised process. Consequently, only through the analysis of the work process, problem finding and solving, and stability maintenance can efficacy be achieved. This clearly explains why Processes plays a key role in Lean management. As the medical care system involves the safety of the general public and the well-being of human beings, no room is left for negligence in its operation. Hence, quality and safety should be taken into account if a balance would like to be achieved in such a competitive healthcare industry.

Products come in second in this category. It indicates that to offer satisfactory services that meet the patient's expectation and to reduce the cost requires proper quality control and an efficient use of resources. Verena (2011) indicated that in hospitals, the importance of the service is clearly defined: patients expect the highest quality of medical treatment and therapies, and patient care is existential. As standards of living advance and people are more aware of their rights as consumers, patients are expecting more on how they are being served. Thus, the efficacy of services has become a factor that decides why a patient chooses a certain hospital.

The results of the study also revealed that Leadership and Partnership are nearly equal in value, while People rank last. This finding indicates that the influence of people is minimal in implementing Lean management, which may occur because healthcare professionals have received thorough training to cope with emergency events, and they have access to newer medical information. Therefore, people are not considered an important criterion.

\subsection{The Ranking of the Sub-criteria}

\subsubsection{Leadership}

Among the four sub-criteria, Patient-centered Care receives the highest value. As Frampton et al. (2008) noted, leadership engagement in any culture-change initiative toward patient-centered care is crucial. It clearly demonstrates that the concept of patient-centered care plays a key role. As a growing number of nations have promoted medical renovations and attention has been oriented toward quality, medical care focusing on 
patient-centered care has become a new model. Under this trend, the medical industry has also begun to reverse its thinking from targeting diseases, physicians, and hospitals to patient-centered care. This trend and the results of the study have verified what we have concluded in the literature review.

Executive Sponsorship and Leadership as well as Integrated Planning for Strategies are nearly equal in value, which indicates that they are important for the leadership category. The goals and direction of a Lean hospital should be planned as a whole. They are tools essential for building up a Lean culture and for disseminating it to the entire organization. Thus, the success of a hospital adopting Lean management relies heavily on the support from the administrators and the physicians. If the upper management is reluctant to get involved and help resolve conflicts and disputes among different departments, then it is rather difficult to successfully carry out Lean management.

Vision and Mission ranks last. Vision and Mission may be very important at the stage of establishing a new hospital; yet, it may become less important after it matures into a comprehensive hospital.

\subsubsection{People}

Among the four sub-criteria, Clearly Defined Work Content and Channels for Advice are both nearly equal in value. The reasons behind this similarity might be due to the popularity of the national health insurance in Taiwan, the ever-increasing amount of medical services required, the prevalent chronic diseases, the aging population, the increasing severity of diseases, and the complexity of clinic care, which might have led to heavy workloads. Under these conditions, the so-called "sweat hospitals" might emerge. When distinctions do not exist between a professional clinic and a non-professional clinic, the role of medical care personnel cannot be developed to its fullest, which may easily lead to malpractice. As a result, a clear list of the duties needs to be urgently set up because it helps ensure that the personnel can follow and abide by it specifically and correctly.

In Taiwan, the top-down approach is the prevailing way of running a hospital; however, it is necessary for the higher-ups to take a more open attitude toward their employees. Only when their employees' opinions are valued can the morale of the employees be increased. As a result, the participation of the employees helps improve the quality, patient safety, and employee engagement.

Motivating Learning and Innovation is ranked relatively less important. For this, the hospitals should focus on standards of operation in medical events, and the employees need to accept education and training of medical skills at a fixed time.

\subsubsection{Partnership}

Among the three sub-criteria, Rewarding Teamwork Effort receives the highest value. In an increasingly competitive environment, teamwork has become a trend. The structure and organization of work for the team apparently has become an important mode of operation (Leigh \& Maynard, 1998). For the medical industry, good teamwork is the foundation of successful medical treatment. However, the importance of teamwork in the practice of healthcare has received the least attention in medical staff education and training. According to the literature and the 2011 Taiwan patient safety reporting system statistics (Joint Commission of Taiwan, 2011), the most common causes of medical abnormal happenings are poor communication and team cooperation. This indicates that teamwork skills have a great impact on the safety of the patients (Yule et al., 2006).

In this category, Treating Partners Fairly and Equally received a value of 0.368 , which indicates that it is also a significant factor. That is to say, the resources should be shared among the colleagues to foster cooperation and trust in order to generate equality and share responsibility if decision making is to be effective. The competitive advantage of an enterprise comes from the DNA of the enterprise. Whether it is within or outside the organization, no one can step out of the supply chain. As a result, if sustainable partnerships are to be established, then it is crucial to cultivate personnel who value teamwork as well as foster the development of employees and business partners, long-term close cooperation, mutual trust, and a win-win environment.

Forming a successful cross-functional team needs to have clear performance standards and expectations. Individuals need to know how well they are performing as a member of the cross-functional team and that evaluation should be separate from the functional department evaluation. In these situations, the team members have two distinct roles, and maintaining a clear distinction is helpful, particularly when the team's decisions require compromise and resources from a functional department. This helps explain why the rewarding teamwork effort is a very important factor.

\subsubsection{Processes}

Among the four sub-criteria, Continual Learning and Upgrading as well as Visual Management received values 
that are nearly equal. With the construction of an internal improvement platform, all employees are encouraged to participate in a learning society that targets innovations, continuous learning, and creativity, only through which will the operation be cost-effective, high in quality, and full of perspectives. Healthcare is a complex process, which makes process management complex; consequently, what a hospital leader has to carry out is to create work surroundings that will significantly reduce errors and damage.

Designing and using a control process that is clear and easy to see can enable the employees to detect what the problems and anomalies are and what is being wasted. This process is to expose the problems for quick and timely solutions. For that reason, visual management is indispensable. The healthcare industry is tremendously devoted to the issues of quality improvement and patient safety. Based on this trend, it is inevitable for hospitals to establish and improve their operating structures and mechanisms using comprehensive standardization, and apply them in daily clinical services. Therefore, compared with the other sub-criteria in the Processes category, the influence of standardized work tends to be lower.

\subsubsection{Products}

Among the three sub-criteria, Increasing the Clinic Quality receives the highest value. The Institute of Medicine (IOM) committee (2001) defines "quality of care" as "the degree to which health services for individuals and populations increase the likelihood of desired health outcomes and are consistent with current professional knowledge." As the level of knowledge and the standard of living of the people in Taiwan have tremendously advanced, they are increasingly demanding high-quality medical care. Consequently, enhancing the quality of care and achieving better clinical outcomes have become the long-term direction of medical institutions.

In this study, Improving Customer Satisfaction received the lowest value $(w=0.177)$. Why was it the least valued? It is quite probable that if the quality of health care is improved, then the customers will express their satisfaction as well. Continuously improving the service quality thereby enhances customer satisfaction (Punnakitikashem et al., 2012).

\subsection{Suggestions}

Healthcare services in Taiwan have undergone many fundamental changes since the inception of the National Health Insurance. Healthcare providers are now facing the ever-rising demands for quality healthcare services and limited reimbursement from the National Health Insurance. How to maintain the healthcare quality and run a hospital cost effectively have become the crucial issues that hospital managers need to address. Under this pressure, the only way to survive is to create a promising strategy. There has been extensive evidence in the literature that Lean management has been instrumental in increasing the healthcare system's capacity without any extra cost.

It takes great resources and effort to implement Lean management in hospitals. As a result, it is not practical to adopt the policy on a one-time basis. Therefore, the managers should identify this link and make their resource distribution decisions accordingly. Though the Toyota Lean production system has been used in the healthcare industry, very few successful cases actually exist. For this reason, the priorities should be clearly listed if success is to be expected.

This study provides as follows the managerial implications for hospitals' senior managers:

1) The success of Lean requires many factors: shaping continuous improvement, pursuing perfection, involving the entire organizational culture, and strengthening teamwork and the mutual trust among team members.

2) Creating a patient-centered environment: The patient comes first in all activities and decisions. This idea is the central tenet of Lean practice in hospitals. It puts the patients' expectations at the center of the procedures. All errors and treatment delays must be prevented.

3) Breaking down departmental silos: This is to create collaborative relationships for all partners and stakeholders by being able to cooperate across value streams instead of optimizing their own area.

4) Be more flexible in responding to customers' needs: When facing fundamental changes, hospitals should conduct a full review to eliminate disparities and an inflexible managing system. Lean cannot be done everywhere quickly; instead, it should start with a model that will help demonstrate the potential of Lean and set an example for others to follow.

To improve their skills and knowledge for implementing Lean management, hospital leaders could use the results of this study. The framework developed in this study could potentially lend itself to many practical applications. This study focuses mainly on domestic medical centers in Taiwan. Other types of hospitals could be 
investigated in future work. A combination of other research methods (such as fuzzy) with AHP could potentially improve the experimental results. For instance, AHP data analysis using fuzzy analytics could make the experimental results closer to human decision-making (Chan \& Kumar, 2007).

\section{References}

Adjekukor, J. A., Aronu, C. O., \& Ogbogbo, G. O. (2015). Evaluation of Team Composition Activities Amongst Health Workers in Nigeria Using Logistic Regression Analysis. Open Science Journal of Statistics \& Application, 3(6), 42-51.

Aguilar-Escobara,V. G., Bourqueb, S., \& Godino-Gallegoc, N. (2015). Hospital kanban system implementation: Evaluating satisfaction of nursing personnel. Investigaciones Europeas de Dirección y Economía de la Empresa, 21(3), 101-110. http://dx.doi.org/ 10.1016/j.iedee.2014.12.001

Chan, F. T., \& Kumar, N. (2007). Global supplier development considering risk factors using fuzzy extended AHP-based approach. Omega, 35(4), 417-431. http://dx.doi.org/10.1016/j.omega.2005.08.004

Cliff, B. (2012). Patient-Centered Care: The Role of Healthcare Leadership. Journal of Healthcare Management, 57(6), 381-383.

Crema, M., \& Verbano, C. (2013). Guidelines for overcoming hospital managerial challenges: A systematic literature review. Therapeutics \& Clinical Risk Management, 9, 427-441. http://dx.doi.org/10.2147/TCRM.S54178

D'Andreamatteo, A., Ianni, L., Lega, F., \& Sargiacomo, M. (2015). Lean in healthcare: A comprehensive review. Health Policy, 119(9), 1197-1209. http://dx.doi.org/10.1016/j.healthpol.2015.02.002

Dahlgaard-Park, S. M., \& Dahlgaard, J. J. (2010). Organizational learnability and Innovability: A system for assessing, diagnosing and Improving Innovations. International Journal of Quality and Service Sciences, 2(2), 153-174. http://dx.doi.org/10.1108/17566691011057339

Dombrowskia, U., \& Mielke, T. (2013). Lean Leadership fundamental principles and their application Systems. Procedia CIRP, 7, 569-574. http://dx.doi.org/10.1016/j.procir.2013.06.034

Frampton, S., Guastello, S., Brady, C., Hale, M., Horowitz, S., \& Smith, S. B. (2008). Patient-Centered Care Improvement Guide. Retrieved from http://patient-centeredcare.org

Graban, M. (2016). Lean hospitals: improving quality, patient safety, and employee engagement, CRC Press, New York, NY.

Gulliford, M., Naithani, S., \& Morgan, M. (2006). What is 'continuity of care'? Journal of Health Service Research Policy, 11(4), 248-250. http://dx.doi.org/10.1258/135581906778476490

Hill, C. W., \& Jones, G. R. (2012). Essentials of Strategic Management, CENGAGE Learning, Boston, MA.

Hsu, Y. L., Lee, C. H., \& Kreng, V. B. (2010). The application of Fuzzy Delphi Method and Fuzzy AHP in lubricant regenerative technology selection. Expert Systems with Applications, 37(1), 419-425. http://dx.doi.org/10.1016/j.eswa.2009.05.068

Hudson, M., Smart, A., \& Bourne, M. (2001). Theory \& practice in SME performance measurement systems. International Journal of Operations \& Production Management, 21(8), 1096-1115. http://dx.doi.org/10.1108/EUM0000000005587

Institute of Medicine. (2001). Crossing the Quality Chasm: A New Health System for the 21st Century. Washington, DC: National Academy Press.

Ishikawa, A., Amagasa, M., Shiga, T., Tomizawa, G., Tatsuta, R., \& Mieno, H. (1993). The max-min Delphi method and fuzzy Delphi method via fuzzy integration. Fuzzy Sets \& Systems, 55(3), 241-253. http://dx.doi.org/10.1016/0165-0114(93)90251-C

Johnson, J., Smith, A., \& Mastro, A. (2012). From Toyota to the Bedside: Nurses Can Lead the Lean Way in Health Care Reform. Nursing Administration Quarterly, 36(3), 234-242. http://dx.doi.org/10.1097/NAQ.0b013e318258c3d5

Joint Commission of Taiwan. (2011). Patient Safety. Retrieved from http://www.jct.org.tw/FrontStage/patient_safety_en.html

Jylhä, T., \& Junnila, S. (2014). Partnership practices and their impact on value creation - reflections from lean management", International Journal of Strategic Property Management, 18(1), 56-65. http://dx.doi.org/10.3846/1648715X.2013.863813 
Kaplan, R. S., \& Norton, D. P. (2005). Harvard Business Review: The balanced scorecard: Measures that drive performance. Retrieved from https://hbr.org/2005/07/the-balanced-scorecard-measures-that-drive-performance

Khalifa, A. S. (2012). Mission, purpose, \& ambitions: redefining the mission statement. Journal of Strategy and Management, 5(3), 236-251. http://dx.doi.org/10.1108/17554251211247553

Koota, P., \& Takala, J. (1998). Developing a performance measurement system for world-class distribution logistics by using activity-based costing and management. Case: Basic metal industries. International Journal of Technology Management, 16(1), 267-280. http://dx.doi.org/10.1504/IJTM.1998.002653

Kuo, Y. F., \& Chen, P. C. (2008). Constructing performance appraisal indicators for mobility of the service industries using Fuzzy Delphi Method. Expert Systems with Applications, 35(4), 1930-1939. http://dx.doi.org/10.1016/j.eswa.2007.08.068

Langabeer, J. R., DelliFraine, J. L., Heineke, J., \& Abbass, I. (2009). Implementation of Lean and Six Sigma quality initiatives in hospitals: A goal theoretic perspective. Operations Management Research, 2(1), 13-27. http://dx.doi.org/10.1007/s12063-009-0021-7

Leigh, A., \& Maynard, M. (1998). Leading Your Team: How to Involve and Inspire Teams. Nicholas Berkley Publishing, London, UK.

Linderman, K., Schroeder, R., Zaheer, S., \& Choo, A. (2003). Six Sigma: a goal-theoretic perspective. Journal of Operations Management, 21(2), 193-203. http://dx.doi.org/10.1016/S0272-6963(02)00087-6

Locke, E. A. (1970). Job satisfaction and job performance: a theoretical analysis. Organizational Behavior and Human Performance, 5(5), 484-500. http://dx.doi.org/10.1016/0030-5073(70)90036-X

Lu, J. F., \& Hsiao, W. C. (2003). Does Universal Health Insurance Make Health Care Unaffordable? Lessons From Taiwan. Health Affairs, 22(3), 77-88. http://dx.doi.org/ 10.1377/hlthaff.22.3.77

Lyle, E. R. (2012). Learning Organisation [AL] Learning. International Journal of Business and Social Science, $3(6), 217-221$.

Marx, T. G. (2015). The impact of business strategy on leadership. Journal of Strategy and Management, 8(2), 110-126. http://dx.doi.org/ 10.1108/JSMA-06-2014-0042

Mostafa, S., Dumrak, J., \& Soltan, H. (2013). A framework for lean manufacturing implementation. Production \& Manufacturing Research, 1(1), 44-64. http://dx.doi.org/10.1080/21693277.2013.862159

Noori, B. (2015). The critical success factors for successful lean implementation in hospitals. International Journal of Productivity \& Quality Management, 15(1), 108-126. http://dx.doi.org/10.1504/IJPQM.2015.065987

Papadopoulos, T., Radnor, Z., \& Merali, Y. (2011). The role of actor associations in understanding the implementation of lean thinking in healthcare. International Journal of Operations and Production Management, 31(2), 167-191. http://dx.doi.org/10.1108/01443571111104755

Parast, M. M. (2010). The effect of Six Sigma projects on innovation \& firm performance. International Journal of Project Management, 29, 45-55. http://dx.doi.org/10.1016/j.ijproman.2010.01.006

Park, C., Occena, L. G., Goodwin, C., \& Payne, A. (1998). Analysis of performance measures-A veteran's home case study. Journal of Nursing Administration, 28(12), 28-35. http://dx.doi.org/10.1097/00005110-199812000-00011

Poksinska, B. (2010). The current state of lean implementation in health care: literature review. Quality Management in Healthcare, 19, 319-329. http://dx.doi.org/10.1097/QMH.0b013e3181fa07bb

Punnakitikashem, P., Buavaraporn, P., Maluesri, P., \& Leelartapin, K. (2012). Health Care Service Quality: Case Example of a Hospital with Lean Implementation, paper presented at the POMS 23 rd Annual Conference; 2012 April 20-23; Chicago, Illinois, U.S.A. Retrieved from http://www.pomsmeetings.org/confproceedings/025/FullPapers/FullPaper_files/025-1232.pdf

Saaty, T. L. (1980). The Analytic Hierarchy Process, McGraw-Hill, New York, NY.

Sayer, N. J., \& Williams, B. (2012). Lean for Dummies. John Wiley \& Sones, Hoboken, NJ.

Su, Y., Soar, J., Shen, N., \& Al-Hakim, L. (2014). Adapted Lean Thinking for Healthcare Services: An Empirical Study in the Traditional Chinese Hospital. In Wickramasinghe, N., Al-Hakim, L., Gonzalez, C and Tan, J. (Eds.), Lean Thinking for Healthcare, Springer, New York, NY, 115-142. 
http://dx.doi.org/10.1007/978-1-4614-8036-5_8

Taiwan Healthcare Reform Foundation. (2016). Healthcare in Taiwan. Retrieved from http://issue.thrf.org.tw/EN/Page_Show.asp?Page_ID=124

Tezel, A., \& Nielsen,Y. (2013). Lean Construction Conformance among Construction Contractors in Turkey. Journal of Management in Engineering, 29(3), 236-250. http://dx.doi.org/10.1061/(ASCE)ME.1943-5479.0000145

Verena, L. S. (2011). Lean Management in Hospitals Principles and Key Factors for Successful Implementation. Druck Diplomica Verlag GmbH, Hamburg, Germany.

Vinodh, S., \& Joy, D. (2012). Structural equation modeling of lean manufacturing practices. International Journal of Production Research, 50(6), 1598-1607. http://dx.doi.org/10.1080/00207543.2011.560203

Winston, B. E., \& Patterson, K. (2006). An integrative definition of leadership. International Journal of Leadership Studies, 1(2), 6-66.

Womack, J. P., \& Jones, D. T. (2005). Lean consumption. Manufacturing Engineer, 84(4). http://dx.doi.org/10.1049/me:20050411

Xyrichis, A., \& Ream, E. (2008). Teamwork: a concept analysis. Journal of Advanced Nursing, 61(2), 232-241. http://dx.doi.org/ 10.1111/j.1365-2648.2007.04496.x.

Yule, S., Flin, R., Paterson-Brown, S., \& Maran, N. (2006). Non-technical skills for surgeons in the operating room: a review of the literature. Surgery, 139, 140-149. http://dx.doi.org/ 10.1016/j.surg.2005.06.017

\section{Copyrights}

Copyright for this article is retained by the author(s), with first publication rights granted to the journal.

This is an open-access article distributed under the terms and conditions of the Creative Commons Attribution license (http://creativecommons.org/licenses/by/4.0/). 